\title{
Foreword
}

\author{
Loïc J. D. Wacquant
}

Of the manifold works by Pierre Bourdieu, The State Nobility is perhaps the most formidable and the most paradoxical, and no doubt for these very reasons likely to disconcert, if not confound, many of its foreign readers. First, it is at once doggedly Francocentric in empirical substance and scope, yet irrepressibly universalizing in analytical intent and reach. Second, and this is one of the hallmarks of Bourdieu's sociological style, The State Nobility is resolutely empirical, data-laden to the point of saturation, yet animated by a forceful theoretical project that places it at the epicenter of debates over power, culture, and reason at century's end.

Even more so than Distinction, which it builds upon and extends in a number of directions, ${ }^{1}$ this study of the logic of social domination in advanced society, and of the mechanisms whereby it disguises and perpetuates itself, is anchored deep in the specificities of the French system of class, culture, and education in the two decades following the upheaval of May 68. At the same time, as in every good ethnological report according to Marcel Mauss, "what may appear as futile detail is in fact a condensation of principles" that Bourdieu contends are equally operative in other countries and epochs.

The first such principle is the vexing yet obdurate relationship of collision and collusion, autonomy and complicity, distance and dependence, between material and symbolic power. As Weber noted well, in every structure of domination, those "privileged through existing political, social, and economic orders" are never content to wield their power unvarnished and to impose their prerogatives naked. Rather, they "wish to see their positions transformed from purely factual power relations into a cosmos of acquired rights, and to know that they are thus sanctified." 3 In feudal society, the Church was the institution entrusted with transmuting the lord's might, founded as it was upon control of weaponry, land, and riches, into divine 


\section{$x$ Foreword}

right; ecclesiastical authority was deployed to justify and thereby solidify the rule of the new warrior class. In the complex societies spawned by late capitalism, Bourdieu maintains, the school has taken over this work of sanctification of social divisions. So that not one but two species of capital now give access to positions of power, define the structure of social space, and govern the life chances and trajectories of groups and individuals: economic capital and cultural capital.

Credentials help define the contemporary social order, in the medieval sense of ordo, a set of gradations at once temporal and spiritual, mundane and celestial, which establish incommensurable degrees of worth among women and men, not only by sorting and allocating them across the different slots that make up the social structure, but also, and more importantly, by presenting the resulting inequalities between them as ineluctable necessities born of the talent, effort, and desire of individuals. This is because cultural capital, though mainly accumulated and handed down in the family, appears to inhere in the person of its bearers. The fact that it "manages to combine the prestige of innate property with the merits of acquisition"4 makes it uniquely suited to legitimizing the continued inheritance of social privileges in societies smitten with the democratic ideal.

Here Bourdieu's object is the operation of social alchemy whereby a social hierarchy dis-simulates itself, to those it dignifies no less than to those it excludes, as a scale of human excellence, how a historically arbitrary social order rooted in the materiality of economic and political power transmutes itself into what displays every outward appearance of an aristocracy of intelligence. Under this angle, the granting of an elite degree is not so much a "rite of passage" à la Van Gennep as a rite of institution:" it does not demarcate a before and an after so much as it differentiates - and elevates those destined to occupy eminent social positions from those over whom they will lord. It evokes reverence for and consecrates them, in the strongest sense of the term, that is, it makes them sacred (anyone who has attended a commencement ceremony at a major British or American university cannot but be struck by their archaic religious feel that would have delighted Robertson Smith). As the etymology of the word "credentials," credentialis, giving authority (derived in turn from credere, to believe), testifies, the bestowal of a diploma is the climactic moment in a long cycle of production of collective faith in the legitimacy of a new form of class rule.

Indeed, much as the "generalization of the ceremony of dubbing" was, according to Marc Bloch, "the symptom of a profound transformation of the notion of knighthood" in the Middle Ages, ${ }^{6}$ Bourdieu argues that the generalization of educational titles as prerequisite for ascent to the apex of 
private corporations and public bureaucracies signals the consolidation of a new mode of domination and a corresponding transformation in the system of strategies whereby the ruling class maintains and masks itself, at the cost of swift and continual self-metamorphosis.

In feudal society, the relation between the temporal and spiritual poles of power took the form of a relatively simple, dualistic yet complementary, opposition between warriors and priests, military and hierocratic authority, wielders of swords and wielders of words. With the constitution of the formally rational state and the concurrent ascendancy of the "second capital" (the two, Bourdieu hypothesizes, are correlative historical inventions), this antagonistic couple is replaced by an immensely complex web of crisscrossing linkages among the multiplicity of fields in which the various forms of social power now effective circulate and concentrate. The chain of interdependencies that sews them together into this peculiar ensemble Bourdieu calls field of power (a notion introduced in the early 1970s but elaborated for the first time here both theoretically and empirically) extends from the economic field, at one end, to the field of cultural production, at the other.? Industrialist and artist in the nineteenth century, manager and intellectual in the twentieth are, in the case of France, the personifications of the dominant and the dominated poles of the field of power respectively. Between them, and in symmetric and inverse order according to the relative preponderancy they accord to economic or cultural capital, are arrayed the fields of politics, higher civil service, the professions, and the university.

As species of capital diversify and autonomous fields multiply - two propositions which, for Bourdieu, are equivalent conceptual translations of the same epochal trend since capital and field mutually define and specify each other - and as the more transparent "mechanical solidarity" between weakly differentiated and interchangeable powers gives way to the more intricate "organic solidarity" between highly distinct and disparate powers, tensions mount and clashes threaten to break out. For the fact that variegated forms of capital now enter into the formula of domination implies that different principles of social primacy and legitimacy must be reckoned with and reconciled. The field of power is precisely this arena where holders of the various kinds of capital compete over which of them will prevail. At stake in these struggles amongst the dominant (oft mistaken for confrontations between ruling and subordinate classes) is the relative value and potency of rival kinds of capital, as set in particular by the going "exchange rate" between economic and cultural currencies.

This is where the system of elite establishments of higher education enters the picture. In societies characterized by the copresence and contest of diverse forms of power that all rely increasingly upon conversion into credentials as a means for self-perpetuation, this system not only guarantees preferential and speedy access to positions of command to the sons of those lineages who already monopolize them (full membership in the nobility, 
whether based on blood or diplomas, is essentially a male affair). Its high degree of autonomy and internal differentiation according to the same antinomy between money and culture that organizes the field of power at large enables it also to defuse intranecine conflicts by recognizing and rewarding diverse claims to scholastic, and thence social, excellence.

"Intellectual schools" such as École Normale Supérieure, the seedbed of France's high intelligentsia (Bourdieu is one in a long string of distinguished alumni), draw and honor mainly those students who are most strongly attracted to them in the first place because their dispositions are living embodiments of the kind of capital these schools demand and valorize, viz. children originating from the cultured fractions of the bourgeoisie to which they promptly return. Establishments geared to grooming captains of industry and state, such as École des Hautes Études Commerciales and École Polytechnique, on the other hand, are primarily the preserve of students issued from, and destined for, the economically rich fractions of the French haute bourgeoisie. Situated at midpoint between the two poles of the space of French elite schools, the École Nationale d'Administration, from which cabinet members and high civil servants hail, mingles the two kinds of competencies, cultural and economic, and recruits students whose family patrimony typically cumulates rare credentials and old wealth.

By providing separate pathways of transmission of privilege and by recognizing competing, even antagonistic, claims to preeminence within its own order, the field of elite schools insulates and placates the various categories of inheritors of power and ensures, better than any other device, the pax dominorum indispensable to the sharing of the spoils of hegemony. Hence it is not this or that establishment but the field (that is, the space of objective relations) they compose that contributes qua field to the reproduction of the evolving matrix of patterned differences and distances constitutive of the social order. The immediate, concrete, object of The State Nobility is the structure and functioning of the uppermost tier of France's system of higher education and its linkages to this country's bourgeoisie and top corporations. Its deeper, theoretic, aim is to elaborate, in the very movement whereby it displays empirically one of its historical instantiations, a model of the social division of the labor of domination that obtains in advanced societies where a diversity of forms of power coexist and vie for supremacy.

\section{III}

Its extreme centralization and high social selectivity, rooted in longstanding ties between class cleavages, state building, republicanism, and education and in the bifurcation between university and grandes écoles, the eagerness with which it sanctifies worldly (that is, bourgeois) cultural baggage and the 
corresponding brutality with which it devalues its own products as "scolaires," all make France's system of higher learning a propitious terrain upon which to expose the surreptitious correlation of academic with social classification and the Janus-faced nexus of connivance-through-conflict between the two poles of the field of power. The specificity of these empirical materials, however, should not detract from the wider applicability of the analytic framework employed to process them. Properly construed, The State Nobility offers a systematic research program on any national field of power, provided that the American (British, Japanese, Brazilian, etc.) reader carries out the work of transposition necessary to generate, by way of homological reasoning, an organized set of hypotheses for comparative inquiry in her own country. ${ }^{8}$

Bourdieu holds that the chiasmatic organization of the contemporary ruling class, expressive of a historical state of the division of labor between material (economic) and symbolic (cultural) capital, ${ }^{9}$ and its projection onto the field of elite schools that both disengages and entwines the two, is characteristic of all advanced societies. But this subterranean structure of opposition takes on phenomenally diverse forms in different countries, depending on a number of intersecting factors, including the historical trajectory of (upper) class formation, state structures, and the shape of the system of education in the society and time under consideration. Similarly, Bourdieu proposes that the rise of the "new capital" translates everywhere into a shift in modes of reproduction, from direct reproduction, where power is transmitted essentially within the family via economic property, to school-mediated reproduction, where the bequeathal of privilege is simultaneously effectuated and transfigured by the intercession of educational institutions. But, again, all ruling classes resort to both modes conjointly (Bourdieu takes pain to stress that the growing relative weight of cultural capital in no way effaces the ability of economic capital to propagate itself autonomically) and their partial preference for one or the other will depend on the full system of instruments of reproduction at their disposal and on the current balance of power between the various fractions tied to this or that mode of transmittance.

It follows that it would be a mistake - Alfred North Whitehead called it the "fallacy of misplaced concreteness"10 - to look for one-to-one correspondences across national boundaries between the institutions entrusted with perpetuating the network of power positions in different societies (for instance, to seek an exact American or British counterpart to the École Nationale d' Administration, for which there is none). Rather, one must, applying the relational mode of thinking encapsulated by the notion of field, set out in each particular case to uncover empirically the specific configurations assumed by the complexus of oppositions that structure social space, the system of education, and the field of power, as well as their interconnections. 
To illustrate summarily, the structure of the space of elite education turns, in the French instance, on a sharp horizontal dualism between grandes écoles (select graduate schools based on a numerus clausus, special preparatory classes, and national competitive entrance examinations, with direct pathways to high-profile jobs) and university (mass institutions open to all those who complete their secondary cursus and only loosely connected to the occupational world) and, within the field of grandes écoles itself, between, along one axis, major and minor schools and, along the other, establishments oriented toward intellectual values and establishments grooming for economic-political positions. In the decentralized American system of education, these dualities are refracted into a whole series of nested oppositions, vertical as well as horizontal: between private and public sectors (starting at the level of secondary schooling), between community colleges and four-year universities, and between the great mass of tertiary educational institutions and a handful of elite establishments (anchored by the Ivy League) that arrogate the lion's share of command posts in private and public affairs alike. ${ }^{11}$ Due to the deep-rooted historic preponderancy of economic over cultural capital, the opposition between the two poles of power, and between the corresponding fractions of the American dominant class, does not materialize itself in the form of rival tracks or schools. It is projected instead within each (elite) university in the adversative and tensionful relations between the graduate division of arts and sciences, on the one side, and professional schools (especially law, medicine, and business) on the other, as well as in the antipodean relations these entertain with the powers-that-be and in the contrasted images of knowledge they appeal to (research versus service, critique versus expertise, creativity versus utility, etc.).

Yet, for all the differences in their respective systemic location and circuitry, the tightly integrated network of Ivy League universities and private boarding schools functions as a close, if partial, analogue to the French device of grandes écoles and their associated classes préparatoires. Since the "mere assertion that elite schools exist, especially socially elite schools, goes against the American grain," 12 it is perhaps not superfluous to recall briefly just how exclusive - and exclusionary - the latter are. Suffice it to note that virtually all graduates of the top US boarding schools (who comprise 1 percent of American high school enrollment) enter college, compared to 76 percent of students from Catholic and other private schools, and 45 percent of all public school seniors. These super-privileged students, nine in ten of whom are children of professionals and business managers (two-thirds of their fathers and one-third of their mothers attended graduate or professional school) are also much more likely to land on the most prized campuses, even controlling for scholastic aptitude scores: in 1982, nearly half of graduating "preppies" applied to Ivy League schools and 42 percent of those applicants were admitted, as against 26 percent of all candidates 
nationwide (though the latter are drawn from the country's top 4 percent of students), thanks to close organizational ties and active recruiting funnels between boarding schools and high status private colleges. ${ }^{13}$

In 1984, a mere 13 elite boarding schools were found to have educated 10 percent of the board members of large US companies and nearly one-fifth of directors of two major firms, as compounding exclusive college degrees with upper-class pedigree multiplies the probability of joining the "inner circle" of corporate power. Among senior managers, possession of prestigious educational credentials interacts with high class origins to decide who will become chief executive, serve on the boards of outside firms, and enter the leadership of major business associations. And just as in France diplomas sanctioning "generalized bureaucratic culture" tend to supersede certificates of technical proficiency, in the United States a top law degree or a bachelor's degree from a select private college gives a manager a greater chance of reaching the vertex of responsibility in the corporate world than a master's degree from a high-ranking MBA program. ${ }^{14}$

Graduates of elite boarding schools and universities coming from wellto-do families listed in the Social Register are also massively overrepresented in the upper reaches of the American state (including the cabinet, the judiciary, and government advisory boards), political personnel, high-priced law firms, the national media, philanthropic organizations, and the arts. ${ }^{15}$ And those who emerge out of the prep crucible to become "powerbrokers" in Boston, Washington, and Los Angeles feel no less entitled to their positions and prerogatives than their counterparts from the rue Saint-Guillaume in Paris.

Distinguishing the (specific) empirical findings from the (general) theoretical model contained in The State Nobility suggests an agenda for a comparative, genetic and structural sociology of national fields of power that would, for each society, catalog efficient forms of capital, specify the social and historical determinants of their degrees of differentiation, distance, and antagonism, and evaluate the part played by the system of elite schools (or functionally equivalent institutions) in regulating the relations they entertain.

Such an inquiry would no doubt confirm that the greater opacity of the school-mediated mode of reproduction, and thus its improved capacity to dissimulate the perpetuation of power, comes at a real price. First, it becomes more and more costly to be an inheritor: elite schools everywhere typically subject their students to stringent work regimens, austere lifestyles, and practices of intellectual and social mortification that entail significant personal sacrifice. Second, the stochastic logic which now 
governs the transmission of privilege is such that, while he enjoys every possible advantage from the start, not every son of chief executive, surgeon, or scientist is assured of attaining a comparably eminent social position at the finish of the race. ${ }^{16}$ The specific contradiction of the school-mediated mode of reproduction resides precisely in the disjunction it creates between the collective interest of the class that the field of elite schools safeguards and the interest of those of its individual members it must inevitably forfeit to do so.

Bourdieu submits that the (limited) downward mobility of a contingent of upper-class youths and the transversal, "deviant trajectories" that take a number of them from one pole of the field of power to the other - as when offspring from the cultured fractions of the bourgeoisie accede to posts of corporate or political responsibility - are powerful sources of change within the field of power as well as major tributaries to the "new social movements" that have flourished in the age of universal academic competition. At any rate, not all heirs are, under this regime, both capable and desirous of shouldering the burdens of succession.

This means that, to realize itself fully, a generative sociology of the manifold logics of power cannot limit itself to drawing an objectivist topology of distributions of capital. It must encompass within itself this "special psychology" that Durkheim called for but never delivered. ${ }^{17}$ It must, that is, give a full account of the social genesis and implementation of the categories of thought and action through which the participants in the various social worlds under investigation come to perceive and actualize (or not) the potentialities they harbor. For Bourdieu, such dissection of the practical cognition of individuals is indispensable because social strategies are never determined unilaterally by the objective constraints of the structure any more than they are by the subjective intentions of the agent. Rather, practice is engendered in the mutual solicitation of position and disposition, in the now-harmonious, now-discordant encounter between "social structures and mental structures," history "objectified" as fields and history "embodied" in the form of this socially patterned matrix of preferences and propensities that constitute habitus. ${ }^{18}$

This is why The State Nobility opens with an analysis of the practical taxonomies and activities through which teachers and students jointly produce the everyday reality of French elite schools as a meaningful Lebenswelt. In part I (chapter 2: "Misrecognition and Symbolic Violence"), Bourdieu takes us inside the mind of the philosophy professor of the École Normale Supérieure so that we may learn how to think, feel, and judge like one and hence grasp from within, as it were, the obviousness of the umbilical - yet continually denied - relation between academic excellence and class distinction. And in part II ("The Ordination"), he reconstructs with painstaking precision and pathos the quasi-magical operations of segregation and aggregation whereby the scholastic nobility is unified in body cum 
soul and infused with the utmost certitude of the justness of its social mission. The thorough (re)making of the self involved in the fabrication of the habitus of the dominant reveals how power insinuates itself by shaping minds and moulding desire from within, no less than through the "dull compulsion" of material conditions from without.

Far from resolving itself in the mechanical interplay of homological structures (and of second-order correspondences between homologies operating at different levels of the field of power and its constituent subfields), Bourdieu is able to show that domination arises in and through that particular relation of im-mediate and infraconscious "fit" between structure and agent that obtains whenever individuals construct the social world through principles of vision that, having emerged from that world, are patterned after its objective divisions. Thus he can affirm at one and the same time, and without contradiction, that social agents are fully determined and fully determinative (thereby dissolving the scholastic alternative between structure and agency).

Paraphrasing Marx's famous formula, one might say that, for Bourdieu, men and women make their own history but they do not make it through categories of their own choosing. And we may also say without succumbing to idealism that social order is, at bottom, a gnoseological order, provided that we concurrently recognize that the cognitive schemata through which we know, interpret, and actively assemble our world are themselves social constructs that transcribe within individual bodies the constraints and facilitations of their originative milieu.

\section{V}

One might be puzzled by the fact that official state structures, policies, and personnel - the stock-in-trade of conventional sociologies of the state hardly turn up in the present book. This deliberate absence is meant to dramatize one of Bourdieu's key arguments: that the state is not necessarily where we look for it (that is, where it silently instructs us to cast our gaze and net), or, more accurately, that its efficacy and effects may be strongest precisely where and when we neither expect nor suspect them. ${ }^{19}$

For Bourdieu, the differentia of the state as an organization born of and geared toward the concentration of power(s) does not lie where materialist theories from Max Weber to Norbert Elias to Charles Tilly typically place it. We remain overly wedded to the (eighteenth-century) view of the state as "revenue collector and recruiting sergeant" when we see in it that agency which successfully monopolizes legitimate physical violence and neglect to notice alongside that it also, and more decisively, monopolizes legitimate symbolic violence. ${ }^{20}$ The state, Pierre Bourdieu intimates, is first and foremost the "central bank of symbolic credit" which endorses all acts of nomination 
whereby social divisions and dignities are assigned and proclaimed, that is, promulgated as universally valid within the purview of a given territory and population. And the academic title is the paradigmatic manifestation of this "state magic" whereby social identities and destinies are manufactured under cover of being recorded, social and technical competency fused, and exorbitant privileges transmuted into rightful dues.

The violence of the state, then, is not exercised solely (or even mainly) upon the subaltern, the mad, the sick, and the criminal. It bears upon us all, in a myriad minute and invisible ways, every time we perceive and construct the social world through categories instilled in us via our education. The state is not only "out there," in the form of bureaucracies, authorities, and ceremonies. It is also "in here," ineffaceably engraved within us, lodged in the intimacy of our being in the shared manners in which we feel, think, and judge. Not the army, the asylum, the hospital, and the jail, but the school is the state's most potent conduit and servant.

Durkheim was in the right when, as the good Kantian that he was, he described the state as a "social brain" whose "essential function is to think," a "special organ entrusted with elaborating definite representations valid for the collectivity." 21 Except that these representations, Bourdieu insists, are those of a class-divided society, not a unified and harmonious social organism, and their acceptance is the product of stealthy imposition, not spontaneous consentaneity. Unlike totemic myths, the "scholastic forms of classification" that provide the basis for the logical integration of advanced nation-states are class ideologies that serve particular interests in the very movement whereby they portray them as universal. The instruments of knowledge and construction of social reality diffused and inculcated by the school are also, and inescapably, instruments of symbolic domination. And thus it is that the credential-based nobility owes the fidelity we grant it, in the twofold sense of submission and belief, to the fact that the "frameworks of interpretations" that the state forges and forces upon us through the school are, to borrow another expression of Kenneth Burke's, so many "acceptance frames"22 that make us gently bow under a yoke we do not even feel.

\section{VI}

In offering, first, an anatomy of the production of the new capital and, second, an analysis of the social effects of its circulation in the various fields that partake in the travail of domination, The State Nobility reveals Bourdieu's sociology "of education" for what it truly is, and has been from its inception: a generative anthropology of powers focused on the special contribution that symbolic forms bring to their operation, conversion, and naturalization. Much as the founding triumvirate of classical sociology was 
preoccupied with religion as the opium, moral glue, and theodicy of nascent capitalist modernity, Bourdieu's abiding interest in the school stems from the role he assigns it as guarantor of the contemporary social order via the state magic that consecrates social divisions by inscribing them simultaneously in the objectivity of material distributions and in the subjectivity of cognitive classifications.

Weber's warning that "patents of education will create a privileged 'caste"' has proved prescient: the technocrats who head today's capitalist firms and government offices have at their disposal a panoply of powers and titles - of property, education, and ancestry - without historical precedent. They need not choose between birth and merit, ascription and achievement, inheritance and effort, the aura of tradition and the efficiency of modernity, because they can embrace them all. And yet, Bourdieu's sober diagnosis of the advent of the state nobility does not condemn us to cynicism and passivity, or to the fake radicalism of the rhetoric of the "politics of culture." For the relative autonomy that symbolic power must of necessity enjoy to fulfill its legitimizing function always entails the possibility of its diversion in the service of aims other than reproduction. This is especially true when the "chain of legitimation" grows ever more extended and intricate, and when domination is wielded in the name of reason, universality, and the common weal.

Reason, Bourdieu argues in pushing historicist rationalism to its limit, is neither a Nietzschean illusionist's trick fueled by the "will to power," nor an anthropological invariant rooted in the immanent structure of human communication as with Habermas, but a potent if frail bistorical invention born of the multiplication of those social microcosms, such as the fields of science, art, law, and politics, in which universal values may be realized, albeit imperfectly. ${ }^{23}$ That an ever greater number of protagonists in the game of domination find it necessary to concoct rational justifications for their actions increases the chance that they will, paradoxically, foster in spite of themselves the forward march of reason.

To play with universality is to play with fire. And the collective role of intellectuals as bearers of the "corporatism of the universal" is to compel temporal powers to live up to, and enforce upon each other, the very norms of reason they invoke, however hypocritically. This puts science - and social science in particular - at the epicenter of the struggles of our age. For the more science is summoned by the dominant on behalf of their rule, the more vital it is for the dominated to avail themselves of its results and instruments. Such is the political meaning and purpose of The State Nobility: to contribute to this rational knowledge of domination which, non obstante the jaded jeremiads of postmodernist prophets, remains our best weapon against the rationalization of domination. 


\section{Notes to Foreword}

1 Pierre Bourdieu, Distinction: A Social Critique of the Judgement of Taste, trans. Richard Nice (1979; Cambridge: Harvard University Press; London: Routledge and Kegan Paul, 1984).

2 Marcel Mauss, Manuel d'ethnographie (1947; 3rd edn, Paris: Bibliothèque Payot, 1989), p. 7.

3 Max Weber, From Max Weber: Essays in Sociology, ed. Hans Gerth and C. Wright Mills (Oxford: Oxford University Press, 1946).

4 Pierre Bourdieu, "Forms of Capital," in John G. Richardson (ed.), Handbook of Theory and Research for the Sociology of Education (New York: Greenwood Press, 1986), p. 245. This article is a condensation of Bourdieu's generalized theory of capital, including the latter's basic forms, their respective properties and mechanisms of conversion, and the specificities of cultural capital.

5 Pierre Bourdieu, "Rites of Institution," in Language and Symbolic Power, trans. Peter Collier (1982; Cambridge: Polity Press; Cambridge: Harvard University Press, 1990), pp. 117-27.

6 Marc Bloch, La société féodale (1930; Paris: Albin Michel, 1968), p. 437.

7 Pierre Bourdieu, "Champ du pouvoir, champ intellectuel et habitus de classe," Scolies 1 (1971), pp. 7-26; the more general concept of field (champ) is discussed synthetically in "Some Properties of Fields," in Sociology in Question, trans. Richard Nice (1980; London and Newbury Park: Sage, 1993); for elaborations and exemplary illustrations, see The Field of Cultural Production, trans. Peter Collier (Cambridge: Polity Press; New York: Columbia University Press, 1993).

8 For a germane discussion of the seducements of ideographic reduction with regard to Bourdieu's analysis of the French university field, see Loïc J. D. Wacquant, "Sociology as Socio-Analysis: Tales of 'Homo Academicus'," Sociological Forum 5 (Winter 1990), pp. 677-89.

9 The historical constitution of the opposition between "money" and "art" in nineteenth-century France is retraced in Pierre Bourdieu, The Rules of Art: Genesis and Structure of the Literary Field (1992; Cambridge: Polity Press, 1996).

10 Alfred North Whitehead, Science and the Modern World (1925; New York: New American Library, 1948), p. 52.

11 On these cleavages, see, respectively, Ira Katznelson and Margaret Weir, Schooling for All: Race, Class, and the Decline of the Democratic Ideal (New York: Basic Books, 1987), esp. pp. 208-21; Barbara Falsey and Barbara Heyns, "The College Channel: Private and Public Schools Reconsidered," Sociology of Education 57 (Apr. 1984), pp. 111-22; Peter W. Cookson Jr and Caroline Hodges Persell, Preparing for Power: America's Elite Boarding Schools (New York: Basic Books, 1985); Steven Brint and Jerome Karabel, The Diverted Dream: Community Colleges and the Promise of Educational Opportunity in America, 1950-1985 (New York and Oxford: Oxford University Press, 1989); William Kingston Powell and Lionel S. Lewis (eds), High Status Track: Studies of Elite Schools and Stratification (Albany: State University of New York Press, 1990). 
12 Cookson and Persell, Preparing for Power, p. 15. The figures that follow are also excerpted from this excellent study, ch. 3 .

13 Caroline Hodges Persell and Peter W. Cookson Jr, "Chartering and Bartering: Elite Education and Social Reproduction," Social Problems 33 (Dec. 1985), pp. 114-29.

14 Michael Useem and Jerome Karabel, "Educational Pathways to Top Corporate Management," American Sociological Review 51 (Apr. 1986), pp. 184-200.

15 Michael Useem, The Inner Circle: Large Corporations and the Rise of Business Political Activity in the US and UK (New York: Oxford University Press, 1984); Cookson and Persell, Preparing for Power, pp. 198-202; Michael Schwartz (ed.), The Structure of Power in America: The Corporate Elite as Ruling Class (New York: Holmes and Meier, 1987); George E. Marcus, Lives in Trust: The Fortunes of Dynastic Families in Late Twentieth-Century America (Boulder: Westview Press, 1991); G. William Domhoff, The Power Elite and the State (New York and Berlin: Aldine, 1993); Steven B. Levine, "The Rise of American Boarding Schools and the Development of a National Upper Class," Social Problems 28 (Apr. 1980), pp. 63-94; and, for a historical perspective, E. Digby Baltzell, Philadelphia Gentlemen: The Making of a National Upper Class (1958; New Brunswick: Transaction Press, 1989). It should further be noted that bona fide membership in the American field of power via elite education continues to be restricted to the white caste (cf. Richard L. Zweigenhaft and G. William Domhoff, Blacks in the White Establishment? A Study of Race and Class in America (New Haven: Yale University Press, 1991).

16 Cookson and Persell stress that the "fit between boarding school attendance and admission to elite circles" is anything but perfect (Preparing for Power, pp. 204ff.) and indicate that children from the American ruling class are increasingly unwilling to endure the self-denial, isolation, psychic pain, and severe allaround life asceticism that bequeathal of power henceforth requires. Not a few of them abandon prep school (or are expelled), try to commit suicide, or simply opt to pursue other, less censorious avocations.

17 "We hold that sociology has not completely achieved its task so long as it has not penetrated into the innermost mind [le for intérieur] of the individual in order to relate the institutions it seeks to explain to their psychological conditions" (Émile Durkheim, "Sociologie religieuse et théorie de la connaissance," Revue de Métaphysique et de Morale 17 (1909), p. 755).

18 For a fuller discussion of the two-way relationship between habitus and field, see Pierre Bourdieu and Loïc J. D. Wacquant, An Invitation to Reflexive Sociology (Chicago: The University of Chicago Press; Cambridge: Polity Press, 1992), pp. 12-19 and 97-140.

19 In this, Bourdieu agrees with the late Philip Abrams, who pointed out (in "Notes on the Difficulty of Studying the State," Journal of Historical Sociology $1: 1$ (1988), pp. 58-89) that one of the main obstacles to the sociology of the state resides in the special ability it has to secrete its own power.

20 Pierre Bourdieu, "Rethinking the State: On the Genesis and Structure of the Bureaucratic Field," Sociological Theory 12: 1 (Mar. 1994), pp. 1-19. Indeed, one might argue that the state must have captured a great deal of symbolic power if it is ever to establish the legitimacy of its use of force. 


\section{xxii Foreword}

21 Émile Durkheim, "Définition de l'État," in Leçons de sociologie (Paris: Presses Universitaires de France, 1950), pp. 89 and 87.

22 Kenneth Burke, Attitudes Towards History (1937; Berkeley: University of California Press, 1984).

23 Pierre Bourdieu, "The Scholastic Point of View," Cultural Antbropology 5 (Nov. 1990), pp. 380-91; and Raisons pratiques. Sur la théorie de l'action (Paris: Seuil, 1994), "Un acte désintéressé est-il possible?," esp. pp. 161-7. For two stimulating interpretations of Bourdieu's proposed "third way" between modernist rationalism and postmodern relativism, see Craig Calhoun, "Habitus, Field, and Capital: Historical Specificity in the Theory of Practice," in his Critical Social Theory: Culture, History, and the Challenge of Difference (Oxford: Blackwell, 1995), pp. 132-61; and Paul Raymond Harrison, "Bourdieu and the Possibility of a Postmodern Sociology," Thesis Eleven 35 (1993), pp. 36-50. 